\title{
Cultivation of shear stress sensitive and tolerant microalgal species in a tubular photobioreactor equipped with a centrifugal pump
}

\author{
Michiel H. A. Michels • Atze Jan van der Goot • \\ Marian H. Vermuë • René H. Wijffels
}

Received: 15 December 2014 /Revised: 1 March 2015 / Accepted: 2 March 2015 / Published online: 20 March 2015

(C) The Author(s) 2015. This article is published with open access at Springerlink.com

\begin{abstract}
The tolerance to shear stress of Tetraselmis suecica, Isochrysis galbana, Skeletonema costatum, and Chaetoceros muelleri was determined in shear cylinders. The shear tolerance of the microalgae species strongly depends on the strain. I. galbana, S. costatum, and C. muelleri exposed to shear stress between 1.2 and 5.4 Pa resulted in severe cell damage. T. suecica is not sensitive to stresses up to $80 \mathrm{~Pa}$. The possibility to grow these algae in a tubular photobioreactor (PBR) using a centrifugal pump for recirculation of the algae suspension was studied. The shear stresses imposed on the algae in the circulation tubes and at the pressure side of the pump were 0.57 and $1.82 \mathrm{~Pa}$, respectively. The shear stress tolerant T. suecica was successfully cultivated in the PBR. Growth of I. galbana, S. costatum, and C. muelleri in the tubular PBR was not observed, not even at the lowest pumping speed. For the latter shear sensitive strains, the encountered shear
\end{abstract}

M. H. A. Michels $\cdot$ M. H. Vermuë $\cdot$ R. H. Wijffels

Bioprocess Engineering, AlgaePARC, Wageningen University, P.O. Box 16, 6700 AA Wageningen, The Netherlands

M. H. Vermuë

e-mail: marian.vermue@wur.nl

R. H. Wijffels

e-mail: rene.wijffels@wur.nl

M. H. A. Michels ( $\bowtie)$

HZ University of Applied Sciences, P.O. Box 364, 4380

AJ Vlissingen, The Netherlands

e-mail: m.michels@hz.nl

\section{A. J. van der Goot}

Food Process Engineering, Wageningen University, P.O. Box 17, 6700 AA Wageningen, The Netherlands

e-mail: atzejan.vandergoot@wur.nl

R. H. Wijffels

Faculty of Biosciences and Aquaculture, University of Nordland, 8049 Bodø, Norway stress levels were in the order of magnitude of the determined maximum shear tolerance of the algae. An equation was used to simulate the effect of possible damage of microalgae caused by passages through local high shear zones in centrifugal pumps on the total algae culture in the PBR. This simulation shows that a culture of shear stress sensitive species is bound to collapse after only limited number of passages, confirming the importance of considering shear stress as a process parameter in future design of closed PBRs for microalgal cultivation.

Keywords Shear stress · Sensitivity · Microalgae · Recirculation pump $\cdot$ Tubular photobioreactor

\section{Introduction}

Skeletonema, Chaetoceros, Phaeodactylum, Isochrysis, Pavlova, and Tetraselmis are frequently used microalgae in feed applications for shellfish in hatcheries (Muller-Feuga 2013). These species would be candidates for large scale production given the increasing demand for microalgal feed of constant and high quality for aquaculture. An increased level of microalgae (components) in fish feed is interesting for the development of fish feed with reduced environmental impact (Draganovic et al. 2013).

For controlled large-scale cultivation of microalgae, closed photobioreactors (PBRs) are often advocated (Borowitzka 1999; Acién et al. 2012). Closed PBRs were combine with low contamination risk and almost no $\mathrm{CO}_{2}$ losses leading to a high productivity. Furthermore, the cultivation can be fully automated and culture conditions can be highly controlled (Pulz 2001). However, hydrodynamic forces evoked by turbulent mixing in closed PBRs may limit the application of these closed systems. These forces must not exceed the level that would lead to detrimental effects (Chisti 2010; Tredici 2010), suggesting the 
importance of limiting the shear stress in such PBR systems to levels that can be tolerated by the microalgae. This is especially important when considering the fact that digestibility of microalgael species is positively related to the fragility of the cells (Gladue and Maxey 1994) and therefore to the way many microalgal species used in aquaculture can be cultivated.

Table 1 summarizes the culture systems being employed for the cultivation of the most frequently used microalgal species for aquaculture. All these species can successfully be grown in bubble columns, bags, and carboys; systems that use aeration for mixing. Other types of PBRs, like horizontal tubular PBRs with a shorter light path to produce microalgae at a higher density, are used by aquaculture facilities more often lately (Zmora et al. 2013). Mixing in these systems is induced through recirculation of the microalgal culture in the tubular PBR using pumps, of which centrifugal pumps and airlift pumps are the most common ones (Alías et al. 2004; Molina et al. 2001). Centrifugal pumps are efficient in gas-liquid mass transfer (Fadavi and Chisti 2005) and energy use (Norsker et al. 2011). However, microalgal productivity can be influenced negatively by using centrifugal pumps, due to cell damage occurring inside the pump (Carvalho et al. 2006). This could be an explanation for the very few records of microalgae species used in aquaculture, which have been successfully cultivated in tubular PBRs with centrifugal pumps (Table 1). It is still not clear if shear stress sensitivity of certain microalgal species enables successful cultivation in closed PBRs. Although shear stress sensitive species are being cultivated in tubular PBRs with airlift pumps, shear stress levels occurring in the tubes of PBRs could already be too high resulting in loss of productivity. Therefore, there is a need to study the relationship between shear stress sensitivity of microalgal strains and shear stress levels encountered in closed PBRs.

The aim of the study is to determine the tolerance to shear stress of four different microalgal species. Shear cylinders were used to quantify the threshold values of shear stress for the different microalgal species. These microalgae species were all tested in a tubular PBR with a variable-frequencydrive centrifugal pump to determine the capability of growth. Growth or lack of growth of microalgae will be related to estimated shear stress levels inside the reactor and shear tolerance levels determined for all four species.

\section{Material and methods}

Organisms and medium

Tetraselmis suecica, Isochrysis galbana, and Skeletonema costatum were obtained from Seasalter Shellfish (Whitsable) Ltd. (Kent, UK), and Chaetoceros muelleri (CCMP 1316) was provided by NIOZ (Royal Netherlands Institute for Sea Research). Walne medium modified from Laing (1991) was used for the cultivation of the microalgal species. The modified Walne medium consists of solution A (macro- and micronutrients), $\mathrm{C}$ (vitamins), and $\mathrm{D}$ (silicate, which is only needed for diatoms). Solution A contains $0.8 \mathrm{~g} \mathrm{FeCl}_{3}, 0.4 \mathrm{~g}$ $\mathrm{MnCl}_{2} \cdot 4 \mathrm{H}_{2} \mathrm{O}, 33.6 \mathrm{~g} \mathrm{H}_{3} \mathrm{BO}_{3}, 45.0 \mathrm{~g}$ EDTA, $20.0 \mathrm{~g} \mathrm{NaH}_{2} \mathrm{PO}_{4}$. $2 \mathrm{H}_{2} \mathrm{O}, 100.0 \mathrm{~g} \mathrm{NaNO}_{3}, 21 \mathrm{mg} \mathrm{ZnCl}_{2}, 20 \mathrm{mg} \mathrm{CoCl}{ }_{2} \cdot 6 \mathrm{H}_{2} \mathrm{O}$, $9.0 \mathrm{mg}\left(\mathrm{NH}_{4}\right)_{6} \mathrm{Mo}_{7} \mathrm{O}_{24} \cdot 4 \mathrm{H}_{2} \mathrm{O}$, and $20 \mathrm{mg} \mathrm{CuSO} \cdot 5 \mathrm{H}_{2} \mathrm{O}$ in $1 \mathrm{~L}$ of distilled water, with the $\mathrm{pH}$ adjusted to 4.0 with concentrated $\mathrm{HCl}$. Solution $\mathrm{C}$ consists of $1.0 \mathrm{~g}$ vitamin $\mathrm{B}_{1}$ and $0.05 \mathrm{~g}$ vitamin $\mathrm{B}_{12}$ in $1 \mathrm{~L}$ of distilled water. Solution $\mathrm{D}$ contains $40.0 \mathrm{~g} \mathrm{Na}_{2} \mathrm{SiO}_{3} \cdot 5 \mathrm{H}_{2} \mathrm{O}$ in $1 \mathrm{~L}$ of distilled water. Medium for maintaining the cultures in Erlenmeyer flasks was made by adding $1 \mathrm{~mL}$ solution $\mathrm{A}, 0.1 \mathrm{~mL}$ solution $\mathrm{C}$, and $2 \mathrm{~mL}$ solution $\mathrm{D}$ per liter of filtered and deironized saline groundwater (30 $\mathrm{g} \mathrm{L}^{-1}$ ). A double dose of solutions A, C, and D was supplied to the culture in the tubular photobioreactor during turbidostat operation to avoid nutrient depletion. Solution D was only added for the cultivation of the diatoms $S$. costatum and C. muelleri.

Generation of shear stress levels tolerance

Batch cultures of T. suecica, I. galbana, and S. costatum from 3-L Erlenmeyer flasks containing $2 \mathrm{~L}$ medium after 1 week of growth at $20^{\circ} \mathrm{C}$ under white fluorescent light $(150 \mu \mathrm{mol}$ photons $\mathrm{m}^{-2} \mathrm{~s}^{-1}$; PAR) were used for shear stress experiments. The three microalgal strains were exposed to different shear stress levels in shear cylinders as Couette devices (Van Riemsdijk et al. 2010). Shear stress exposed to the microalgae can be determined with:

$\tau=\dot{\gamma} \cdot \eta$

where $\tau$ is the shear stress $(\mathrm{Pa}), \dot{\gamma}$ is the shear rate $\left(\mathrm{s}^{-1}\right)$, and $\eta$ is the apparent viscosity ( $\mathrm{Pa} \mathrm{s}$ ). Shear stress levels can be varied by increasing the shear rate or by increasing the apparent viscosity of the medium. The shear rate applied in the shear cylinders is related to the rotational speed with a conversion factor of rotational speed (rpm) to shear rate $\left(\mathrm{s}^{-1}\right)$ of 2.157 (Michels et al. 2010). Locust bean gum (LBG), which does not affect the viability directly (Michels et al. 2010), was used as a thickener to increase the apparent viscosity.

S. costatum and I. galbana with $0.3 \%$ LBG in the medium were exposed to different shear rates of $0,8.6,43,216$, and $1079 \mathrm{~s}^{-1}$. T. suecica also was exposed to the same shear rates, but with two LBG concentrations: 0.5 and $0.75 \%$ LBG, to obtain higher viscosity. All exposures were done in triplicate at $4{ }^{\circ} \mathrm{C}$ with an exposure time of $1 \mathrm{~h}$. Since LBG solutions can be described as non-Newtonian fluids, the apparent viscosity was measured at the different shear rates in order to calculate the applied shear stress levels. The shear stress levels applied in the shear cylinders were determined with a rheometer (type Physica MCR 301, Anton Paar) at $4{ }^{\circ} \mathrm{C}$ according to the method described in Michels et al. (2010). The power-law 
Table 1 Most frequently used microalgal species as feed for larvae of mollusks, shrimp, and live prey for fish larvae and their culture systems

\begin{tabular}{|c|c|c|c|c|}
\hline Class & Species & Culture system & Mixing & References \\
\hline \multirow[t]{11}{*}{ Bacillariophyceae } & \multirow[t]{3}{*}{ Skeletonema costatum } & Raceway & Air & Hussenot et al. (1998) \\
\hline & & Polyethylene bags & Air & Pronker et al. (2015) \\
\hline & & Airlift PBR, bubble column & Airlift, air & Monkonsit et al. (2011) \\
\hline & \multirow{4}{*}{$\begin{array}{l}\text { Chaetoceros muelleri, } \\
\text { Chaetoceros gracilis, } \\
\text { Chaetoceros calcitrans }\end{array}$} & Polycarbonate carboys & Air & Camus and Zeng (2012) \\
\hline & & Polyethylene bags & Air & $\begin{array}{l}\text { Kaspar et al. (2014); Pronker } \\
\text { et al. (2015) }\end{array}$ \\
\hline & & Bubble column & Air & Lee et al. (2011) \\
\hline & & Airlift PBR, bubble column & Airlift, air & Krichnavaruk et al. (2005) \\
\hline & \multirow[t]{4}{*}{ Phaeodactylum tricornutum } & Polyethylene bags & Air & Pronker et al. (2015) \\
\hline & & Bubble column & Air & Lee et al. (2011) \\
\hline & & Tubular PBR & Airlift & Acién Fernández et al. (2000) \\
\hline & & Tubular PBR & Centrifugal pump & Silva Benavides et al. (2013) \\
\hline \multirow[t]{8}{*}{ Prymnesiophyceae } & \multirow[t]{6}{*}{ Isochrysis galbana } & Polycarbonate carboys & Air & Camus and Zeng (2012) \\
\hline & & Polyethylene bags & Air & $\begin{array}{l}\text { Dunstan et al. (1993); Kaspar et al. } \\
\text { (2014); Pronker et al. (2015) }\end{array}$ \\
\hline & & Bubble column & Air & Lee et al. (2011) \\
\hline & & Airlift PBR & Airlift & Loubière et al. (2009) \\
\hline & & Tubular PBR & Airlift & $\begin{array}{l}\text { Molina Grima et al. (1994); Van Bergeijk } \\
\text { et al. (2010) }\end{array}$ \\
\hline & & Tubular PBR & Centrifugal pump & Van Bergeijk et al. (2010) \\
\hline & \multirow{2}{*}{$\begin{array}{l}\text { Pavlova lutheri, } \\
\text { Pavlova salina }\end{array}$} & Polycarbonate carboys & Air & Camus and Zeng (2012) \\
\hline & & Polyethylene bags & Air & Dunstan et al. (1993); Pronker et al. (2015) \\
\hline \multirow[t]{6}{*}{ Prasinophyceae } & \multirow{6}{*}{$\begin{array}{l}\text { Tetraselmis suecica, } \\
\text { Tetraselmis chuii }\end{array}$} & Polycarbonate carboys & Air & Camus and Zeng (2012) \\
\hline & & Polyethylene bags & Air & Moheimani (2013); Pronker et al. (2015) \\
\hline & & Bubble column & Air & Lee et al. (2011) \\
\hline & & Annular column & Air & Chini Zittelli et al. (2006) \\
\hline & & Green wall panel reactor & Air & Bondioli et al. (2012) \\
\hline & & Tubular PBR & Centrifugal pump & Michels et al. (2014) \\
\hline
\end{tabular}

functions that describe the relation between shear rate and shear stress in $0.3,0.5$, and $0.75 \%$ LBG are $\tau=0.034 \gamma^{0.943}$ with $R^{2}=0.9998, \tau=0.227 \dot{\gamma}^{0.763}$ with $R^{2}=0.993$ and $\tau=1$. $175 \gamma^{0.618}$ with $R^{2}=0.987$, respectively. These functions were used to calculate the shear stress levels applied at different rotational speed levels and LBG concentrations. Table 2 presents the calculated shear stress levels related to rotational speed, shear rate, and LBG concentration.

\section{Measurement of effect of shear stress on viability}

The effect of applying shear stress on the viability of T. suecica, S. costatum, and I. galbana was measured by using fluorescein diacetate (FDA). Viable cells contain esterases that convert FDA into fluorescein and diacetate. Viable cells show fluorescence caused by fluorescein (Altman et al. 1993; Rotman and Papermaster 1966). After exposure in the shear cylinders, $1 \mathrm{~mL}$ of algae was incubated with $10 \mu \mathrm{L}$ FDA solution $(11 \mathrm{mM})$ for $20 \mathrm{~min}$. The total cell concentration and viable cell concentration were determined with a hemocytometer (DHC-B02-5 Büker Türk) using a fluorescence microscope. The viability of the sheared algae was calculated as the percentage of fluorescing algae and compared to the shear stress tolerance of C. muelleri (Michels et al. 2010).

Table 2 Shear stress applied in relation with rotational speed, shear rate, and LBG concentration

\begin{tabular}{lllll}
\hline $\begin{array}{l}\text { Rotational } \\
\text { speed } \\
(\mathrm{rpm})\end{array}$ & $\begin{array}{l}\text { Shear } \\
\text { rate } \\
\left(\mathrm{s}^{-1}\right)\end{array}$ & $\begin{array}{l}\text { Shear stress } \\
0.3 \% \text { LBG } \\
(\mathrm{Pa})\end{array}$ & $\begin{array}{l}\text { Shear stress } \\
0.5 \% \text { LBG } \\
(\mathrm{Pa})\end{array}$ & $\begin{array}{l}\text { Shear stress } \\
0.75 \% \mathrm{LBG} \\
(\mathrm{Pa})\end{array}$ \\
\hline 0 & 0 & 0 & 0 & 0 \\
4 & 8.6 & 0.26 & 1.2 & 4.5 \\
20 & 43 & 1.2 & 4.0 & 12 \\
100 & 216 & 5.4 & 14 & 33 \\
500 & 1079 & 25 & 47 & 88 \\
\hline
\end{tabular}


Because $S$. costatum can form chains up to $8-10$ cells per chain, the effect of shear stress on the distribution in the number of cells per chain was also measured. The number of cells per chain was counted for at least 50 chains per sample. The MannWhitney $U$ test was done to determine any statistical differences in cells per chain distribution per applied shear stress.

Growth of microalgae in a tubular photobioreactor

Growth tests with $T$. suecica, I. galbana, S. costatum, and C. muelleri were carried out in a tubular PBR with a total volume of $40 \mathrm{~L}$. The tubular PBR consists of 20-m-long loop connected to a degasser. The loop is made of Plexiglas tubes with an external diameter of $50 \mathrm{~mm}$ and an internal diameter $43.6 \mathrm{~mm}$. This culture system is equipped with a variablefrequency-drive centrifugal pump (SealPro KR-32-95, ARBO) with an impeller diameter of $95 \mathrm{~mm}$ and a pressure side diameter of $32 \mathrm{~mm}$, to circulate the microalgal culture. The location and main operating mode of the tubular PBR are described in Michels et al. (2014).

The four microalgal species were separately used for inoculation of the tubular PBR with a minimal starting cell concentration of 200,000 cells $\mathrm{mL}^{-1}$. Temperature was controlled at $20 \pm 0.5^{\circ} \mathrm{C}$. The $\mathrm{pH}$ is measured at the end of the tube before the degasser and controlled at $\mathrm{pH} 8.40$ via $\mathrm{CO}_{2}$ supply. The initial pumping speed at which the microalgae were recirculated was $0.37 \mathrm{~m} \mathrm{~s}^{-1}$, with a rotational speed of the impeller of $10 \mathrm{~s}^{-1}$.

The increase in cell concentration was followed by taking daily samples for 7 days. The run in the PBR was terminated when the cell concentration of an algae species did not increase during this period. The PBR was cleaned thoroughly and inoculated with the same species for a second time. The daily samples were inspected with a microscope to check the shape of the microalgae cells, the motility of the flagellates and potential bacterial occurrence.

The runs in which the algae concentration increased during the first 7 days were further used to study the effect of pumping speed on the net volumetric productivity at turbidostat conditions, with the biomass concentration set at about $0.5 \mathrm{~g} \mathrm{~L}^{-1}$. The pumping speed of the recirculation pump was $2.0,2.4,2.8,3.2$, and $3.6 \mathrm{~m}^{3} \mathrm{~h}^{-1}$, respectively. Those trials were done for a period of 14 days.

Calculation of shear stress levels in the tubular photobioreactor

The corresponding flow velocities and Reynolds numbers in the tubes and at the pressure side of the pump were calculated, with a known culture density of $1024 \mathrm{~kg} \mathrm{~m}^{-3}$ and an apparent viscosity of $1.8 \cdot 10^{-3} \mathrm{~Pa}$ s (Michels et al. 2010). Those conditions were used to estimate the average shear stress levels in the tubes. The Blasius equation was used to calculate the shear stress at the wall of the tube where flow will be laminar (Durst et al. 1996). The equation is:

$\tau=C_{\mathrm{f}} \frac{1}{2} \rho \bar{u}^{2}$

with $C_{\mathrm{f}}=0.0791 R e^{-1 / 4}$

where $\tau$ is the average shear stress $(\mathrm{Pa}), C_{\mathrm{f}}$ is the Fanning friction factor (dimensionless), $\rho$ is the density $\left(\mathrm{kg} \mathrm{m}^{-3}\right), \bar{u}$ is the average flow velocity $\left(\mathrm{m} \mathrm{s}^{-1}\right)$, and $R e$ is the Reynolds number. The Reynolds number is expressed by:

$R e=\frac{\rho \cdot \bar{u} \cdot D}{\eta}$

where $D$ is the internal diameter (m).

The shear stress in the centrifugal pump depends on the apparent viscosity, rotational speed of the impeller, and the Reynolds number. The local shear stress adjacent to the rotating impeller of the centrifugal pump can be estimated with:

$\tau=6.30 \eta N R e_{L}^{0.5}$

where $N$ is the rotational speed of the impeller and the local Reynolds number at the local diameter is defined as:

$R e_{\mathrm{L}}=\frac{N d_{\mathrm{L}}^{2} \rho}{\eta}$

where $d_{\mathrm{L}}$ is the local diameter of the impeller (Chisti 2010; Wichterle et al. 1996).

Determination of the net volumetric productivity

The net volumetric productivity $\left(P_{\mathrm{V}}, \mathrm{g} \mathrm{L}^{-1}\right.$ day $\left.^{-1}\right)$ was determined as the product of the net-specific growth rate $\left(\mu, \mathrm{d}^{-1}\right)$ and the biomass concentration $\left(C_{\mathrm{X}}, \mathrm{g} \mathrm{L}^{-1}\right)$. At turbidostat conditions, the net-specific growth rate is equal to the dilution rate $\left(\mathrm{D}, \mathrm{d}^{-1}\right)$, defined as the daily harvest volume divided by the volume of the PBR (Michels et al. 2014).

The daily photon fluxes were derived from the measured photosynthetically active radiation (PAR) as an average daily incident photon flux density (PFD, mol photons $\mathrm{m}^{-2}$ day $^{-1}$ ) (Michels et al. 2014). The PFD was measured with a LiCor LI190 PAR sensor.

The average daily photon flux density during culture ranged from 0.69 to $13.3 \mathrm{~mol}$ photons $\mathrm{m}^{-2}$ day $^{-1}$. 


\section{Results and discussion}

Shear stress tolerance

Figure 1 shows the effect of shear stress on the viability of T. suecica, I. galbana, S. costatum, and C. muelleri. An adverse effect was found for I. galbana, where viability decreased suddenly to $74.9 \%$ evoked by a shear stress level of $5.4 \mathrm{~Pa}$. The viability of I. galbana was not reduced any further when the shear stress increased to $25 \mathrm{~Pa}$. I. galbana is a flagellate and a member of the non-calcified coccolithophytes with only a plasma membrane covering, which makes the naked cell fragile (Graham et al. 2009b; Zhu and Lee 1997).

The effect of shear stress on $S$. costatum was a bit different. The viability of $S$. costatum decreased further from 80.5 to $73.4 \%$, when the shear stress increased from 5.4 to $25 \mathrm{~Pa}$. This observation can be ascribed to a change in morphology of $S$. costatum due to the increased shear stress. Since this diatom forms chains, breakages of the chains were expected at higher shear stress levels (Sauriau and Baud 1994). The effect of shear stress on the distribution of cells per chain is shown in Fig. 2. The distribution of cells per chain of unexposed $S$. costatum and cells exposed to shear stress of $0.26 \mathrm{~Pa}$ did not differ, while significant differences in distribution of cells per chain were found between all the exposed shear stress levels. Shear stress levels higher than $0.26 \mathrm{~Pa}$ caused a significant reduction in the average chain length with a progressive increase of chains with 1-3 cells. The average chain length reduced linearly on a semi-logarithmic scale from $3.46 \pm 0.18$ to $2.49 \pm 0.04$ cells per chain with corresponding shear stresses of 0.26 and $25 \mathrm{~Pa}$. Although a shear stress of $1.2 \mathrm{~Pa}$ already caused a reduction of the average number of cells per chain, the viability did not decrease significantly (Fig. 1). Shear stress probably has first an impact on the intercellular junctions causing chain breakage, which is then followed by other cell structures like the siliceous frustules being damaged causing mortality (Sauriau and Baud 1994).

Data of $C$. muelleri were used as reference and were obtained from Michels et al. (2010). C. muelleri was found to be shear stress sensitive with a threshold value of shear stress between 1 and 1.3 Pa. Higher shear stress levels caused a decrease in viability with a certain fraction of the cells being sensitive to shear stress (Michels et al. 2010).

T. suecica exposed to shear stress levels up to $88 \mathrm{~Pa}$ did not show any adverse effects on the viability (Fig. 1). The tolerance to high shear stress of T. suecica is probably caused by the rigid cell wall composed of layers of scales attached to the cell membrane (Graham et al. 2009a).

For the algae species that were susceptible to shear stress, the viability was decreased with 20 to $40 \%$. The fact that not all cells were inactivated could be explained by the fact that cells are not equally susceptible to shear damage during the full growing cycle. It has been reported that microalgae are more vulnerable to shear stress during cell division (García Camacho et al. 2007; Stoecker et al. 2006). This will cause a loss of viability of only a certain percentage of the shear stress sensitive species I. galbana, S. costatum, and C. muelleri (Fig. 1). A plausible explanation why the flagellate $T$. suecica is not shear stress sensitive during cell division, is that the
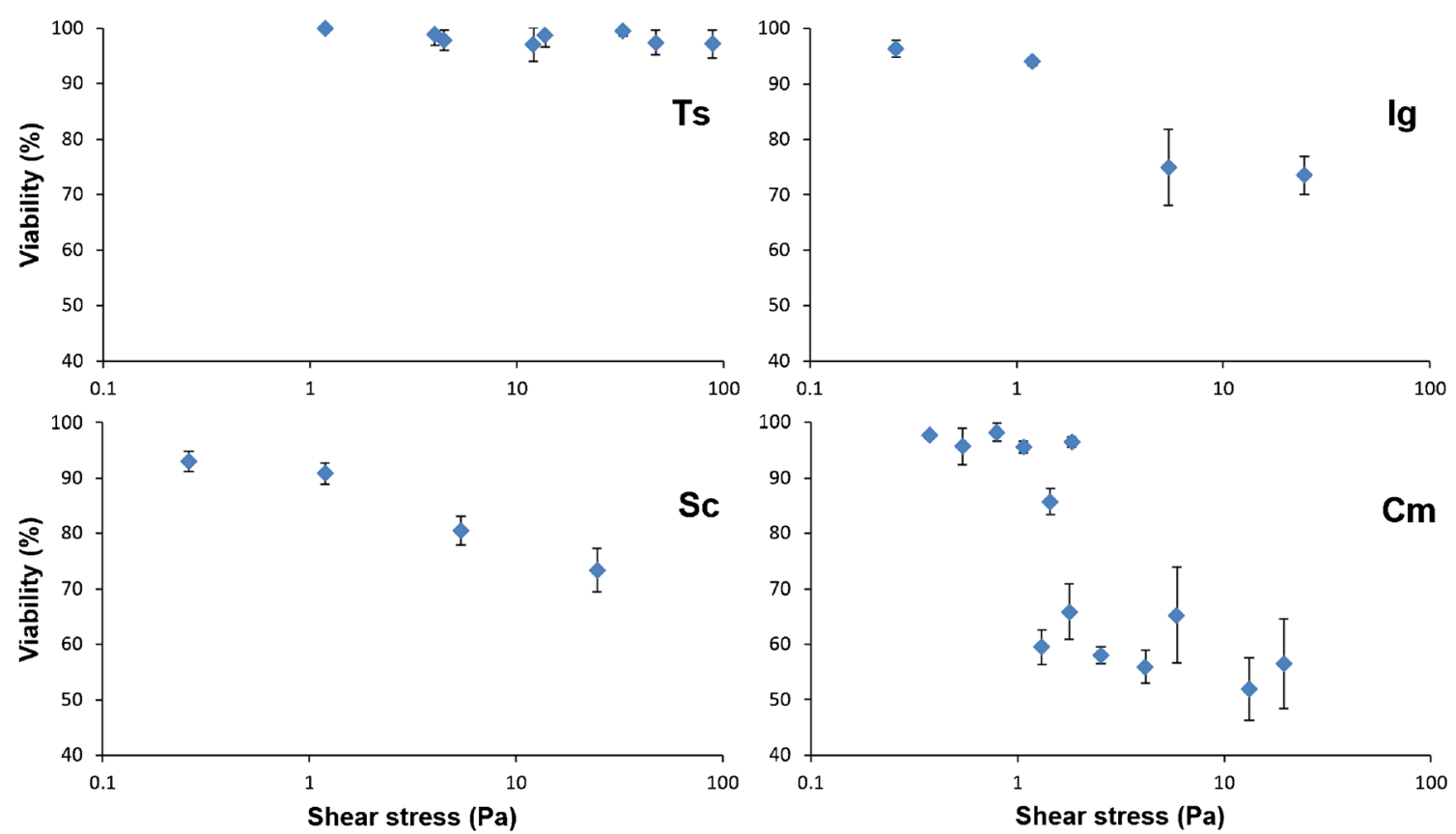

Fig. 1 Effect of shear stress on Tetraselmis suecica (Ts), Isochrysis galbana (Ig), Skeletonema costatum (Sc), and Chaetoceros muelleri (Cm). Data from effect of shear stress on Chaetoceros muelleri were obtained from Michels et al. (2010) 


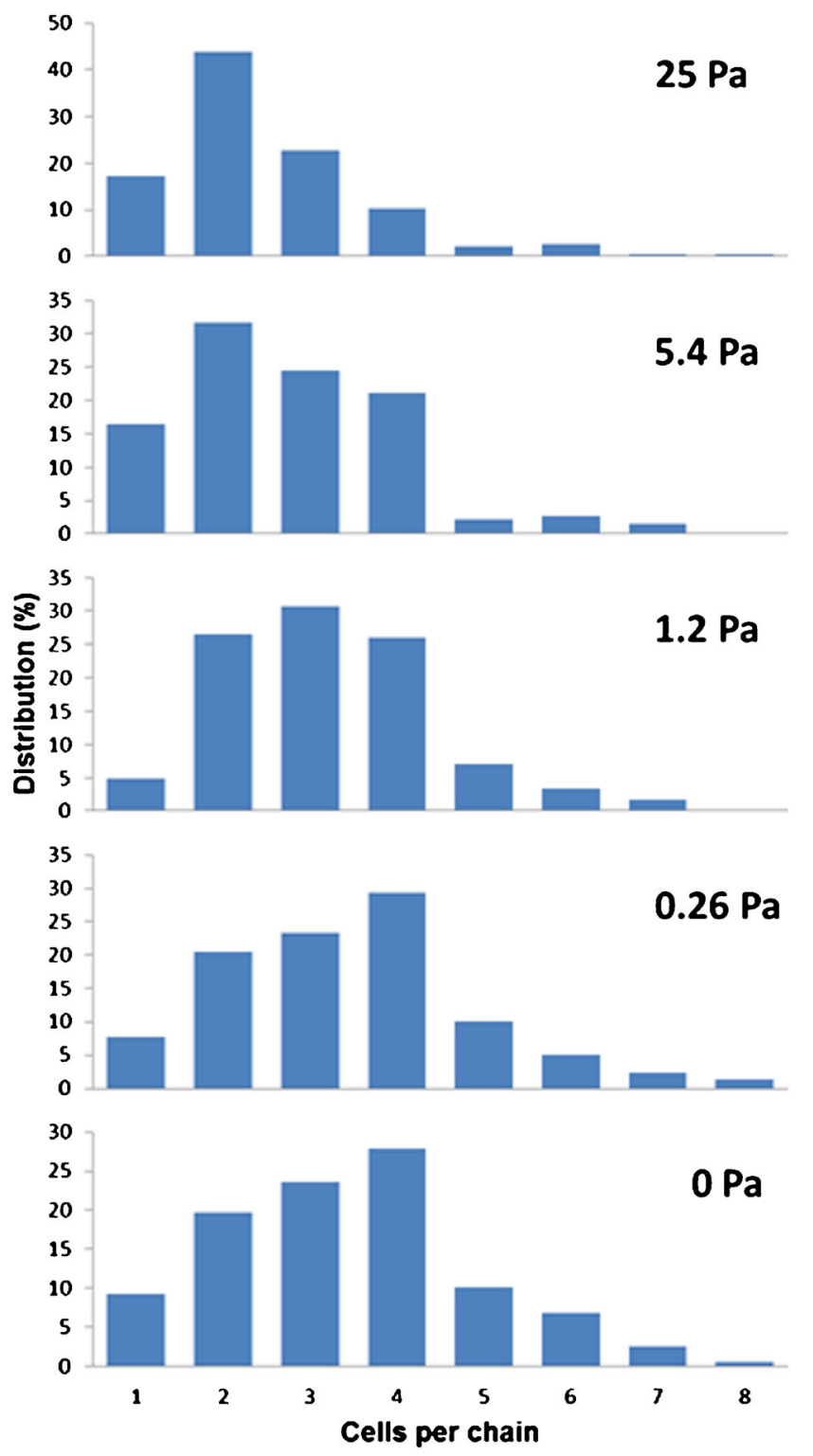

Fig. 2 Effect of shear stress on the distribution of cells per chain of Skeletonema costatum

flagella are shed during the division prior to mitosis, and cytokinesis takes place within the rigid parental wall (Graham et al. 2009a).

Growth tests with shear stress sensitive and tolerant microalgal species

T. suecica, I. galbana, S. costatum, and C. muelleri were all tested for their capability to grow in a tubular PBR in which the culture is recirculated using a centrifugal pump. T. suecica was the only species tested that grew well in the tubular PBR. The net volumetric productivity of $T$. suecica cultivated at different pumping speeds is shown in Fig. 3. The biomass concentration was kept constant at $0.52 \pm 0.05 \mathrm{~g} \mathrm{~L}^{-1}$ applying turbidostat conditions. The net volumetric productivity

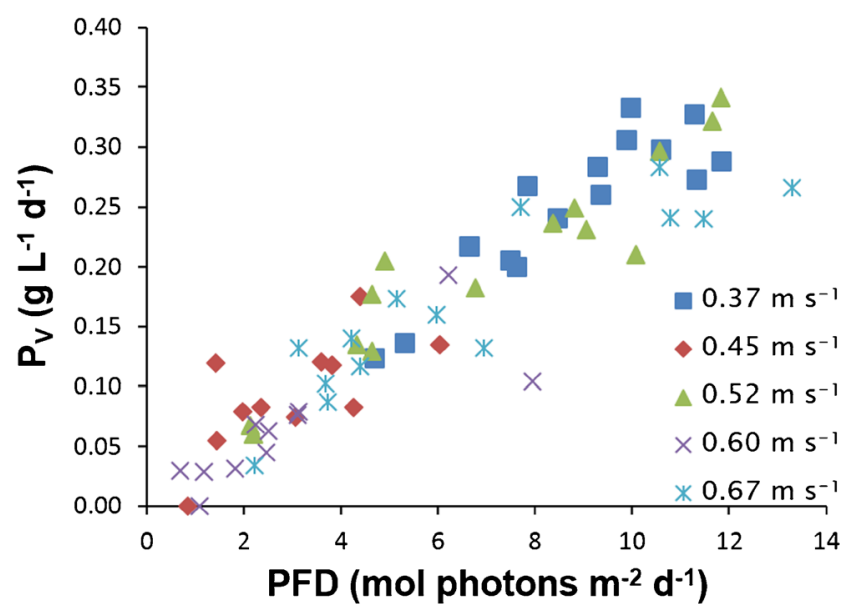

Fig. 3 Net volumetric productivity of Tetraselmis suecica versus the daily photon flux density at different pumping speeds

linearly increased with the daily photon flux received. During the entire experiment, the microalgae were exposed to relatively low light intensity. At these low light intensities, no light saturation or light inhibition occurs. A linear increase of productivity with light input is therefore to be expected (Geel et al. 1997).

No differences in net volumetric productivity of T. suecica receiving similar light were found between the cultivation periods at different pumping speeds. Higher pumping speed evokes increased shear stress and could affect the net productivity negatively by its potential detrimental effects on the microalgae. On the other hand, it can also have a positive effect on the net volumetric productivity due to a better mass and gas transfer and shorter light/dark cycles that are produced when mixing is increased (Contreras et al. 1998; Leupold et al. 2013; Vejrazka et al. 2012). Neither negative nor positive effects of pumping speed on the productivity of $T$. suecica, however, were found during this study.

The average net volumetric productivities with corresponding average daily photon flux densities for the five runs with a different pumping speed are given in Table 3. During the experimental period at limiting light conditions during the fall, the maximum net volumetric productivity of the microalgae receiving a daily photon flux density of 11.8 mol photons $\mathrm{m}^{-2}$ day $^{-1}$ was $0.34 \mathrm{~g} \mathrm{~L}^{-1}$ day $^{-1}$, while daily light inputs lower

Table 3 Average net volumetric productivity and average daily photon flux density at different runs

\begin{tabular}{lll}
\hline $\begin{array}{l}\text { Pumping speed } \\
\left(\mathrm{m}^{3} \mathrm{~h}^{-1}\right)\end{array}$ & $\begin{array}{l}\text { Net volumetric } \\
\text { productivity }\left(\mathrm{g} \mathrm{L}^{-1} \mathrm{day}^{-1}\right)\end{array}$ & $\begin{array}{l}\text { Daily photon flux density } \\
\left(\mathrm{mol} \mathrm{m}^{-2} \mathrm{day}^{-1}\right)\end{array}$ \\
\hline 2.0 & $0.25 \pm 0.06$ & $8.76 \pm 2.17$ \\
2.4 & $0.09 \pm 0.05$ & $3.02 \pm 1.58$ \\
2.8 & $0.20 \pm 0.09$ & $7.14 \pm 3.35$ \\
3.2 & $0.07 \pm 0.05$ & $2.94 \pm 2.23$ \\
3.6 & $0.17 \pm 0.08$ & $6.66 \pm 3.56$ \\
\hline
\end{tabular}


than $1 \mathrm{~mol}$ photons $\mathrm{m}^{-2}$ day $^{-1}$ resulted in a zero or close to zero productivity (Fig. 3). The daily photon flux density of 1 mol photons $\mathrm{m}^{-2}$ day $^{-1}$ was obviously the compensation point of photosynthesis, at which the rate of photosynthesis equals the respiration rate. The compensation point of photosynthesis of $T$. suecica was similar to the value of Chlamydomonas reinhardtii (Takache et al. 2010).

\section{Biofouling at high pumping speed}

Although the highest pumping speed did not lead to a lower net volumetric productivity, the culture of T. suecica was affected negatively. Biofouling started to occur in the tubes 1 day after the pumping speed was set at $3.6 \mathrm{~m}^{3} \mathrm{~h}^{-1}$, at which the average shear stress in the tubes and at the pressure side of the pump were 1.60 and $5.10 \mathrm{~Pa}$, respectively (Table 4). Due to the presence of most of the biofouling at the bottom of the tubes, the cells were still able to receive light, which did not result in a lower net volumetric productivity. Biofouling in the tubes increased enormously during the 2 weeks $T$. suecica was cultivated at this high pumping speed. Therefore, T. suecica should be cultured at lower pumping speeds to ensure cells will not be damaged. An additional benefit of applying a lower pumping speed is the lower energy costs.

Growth of recirculated I. galbana, S. costatum, and C. muelleri in the tubular PBR was not observed, not even at the lowest pumping speed of $2.0 \mathrm{~m}^{3} \mathrm{~h}^{-1}$. The cell concentration of these three microalgae species did not increase during the 7 days tested. General observations in chronological order were a decrease of cell concentration within 1 or 2 days, an increase of number of bacteria, followed by foam formation and finally biofouling. In the case of I. galbana, the remaining viable cells did not lose their motility and no alteration of the shape could be observed. Regarding S. costatum, longer chains disappeared after 1 day with more short chains and single cells as a result. Broken and disintegrated cells of $S$. costatum were seen after a few days. The shape of the remaining cells of $C$. muelleri did not change immediately, but after only a few days the cells became spherical and lost their spines. Shear stress most likely caused the incapability of
I. galbana, S. costatum, and C. muelleri to grow in the tubular PBR.

Relative high shear-stress levels encountered in the photobioreactor

Lack of growth of these microalgae strains could be correlated to the shear stress sensitivity of the cells investigated. Unfortunately, exact shear stress values are difficult to predict in turbulent flow, but the stress at the wall can be calculated easily, due to the fact that flow is laminar at the wall. The shear stress at the wall is $0.57 \mathrm{~Pa}$ at a pumping speed of $2.0 \mathrm{~m}^{3} \mathrm{~h}^{-1}$. A similar calculation leads to a wall shear stress of $1.82 \mathrm{~Pa}$ in the pressure side of the pump (Table 4). It can be expected that even higher shear stress values can occur in other parts of the reactor. For example, maximum shear stress levels of about $2 \mathrm{~Pa}$ were reported in bends of tubes with similar diameters $(5 \mathrm{~cm})$ and at similar velocity $\left(0.35 \mathrm{~m} \mathrm{~s}^{-1}\right)$ in the tubes based on computational fluid dynamics (Ramírez-Duque and Ramos-Lucumi 2011). Even higher shear stress levels will occur in the cavity of the centrifugal pump, where the shear forces are not equally distributed. With an impeller of $95 \mathrm{~mm}$ and rotational speed of $10 \mathrm{~s}^{-1}$, the maximum shear stress occurring in the centrifugal pump could be calculated. The maximum shear stress at the tip of the impeller in the centrifugal pump at a pumping speed of $2.0 \mathrm{~m}^{3} \mathrm{~h}^{-1}$ is $26 \mathrm{~Pa}$. Comparing this shear stress level with the shear stress that evokes loss of viability of the cells (Fig. 1), it is obvious that local shear stress in the pump must have been detrimental to the shear stress sensitive microalgae species. However, a large part of the reactor might still have favorable conditions for cell cultivation.

Simulation of the possible damage caused by high circulation rates

Unfortunately, the high circulation rate of the culture will inevitably lead to the situation that all cells will pass a high shear zone and most of them will pass the zone several times. This can be demonstrated by a simple simulation as shown below. In this simulation, it is assumed that a shear sensitive cell will
Table 4 Flow velocities, Reynolds numbers, and average shear stress levels in tubes and at pressure side of the pump at different pumping speeds

\begin{tabular}{|c|c|c|c|c|c|c|}
\hline \multirow[b]{2}{*}{$\begin{array}{l}\text { Pumping } \\
\text { speed }\left(\mathrm{m}^{3} \mathrm{~h}^{-1}\right)\end{array}$} & \multicolumn{3}{|l|}{ Tubes } & \multicolumn{3}{|c|}{ Pressure side of pump } \\
\hline & $\begin{array}{l}\text { Flow } \\
\text { velocity }\left(\mathrm{m} \mathrm{s}^{-1}\right)\end{array}$ & $\begin{array}{l}\text { Reynolds } \\
\text { number }\end{array}$ & $\begin{array}{l}\text { Average } \\
\text { shear } \\
\text { stress }(\mathrm{Pa})\end{array}$ & $\begin{array}{l}\text { Flow velocity } \\
\left(\mathrm{m} \mathrm{s}^{-1}\right)\end{array}$ & $\begin{array}{l}\text { Reynolds } \\
\text { number }\end{array}$ & $\begin{array}{l}\text { Average s } \\
\text { hear stress }(\mathrm{Pa})\end{array}$ \\
\hline 2.0 & 0.37 & $9.2 \cdot 10^{3}$ & 0.57 & 0.69 & $1.3 \cdot 10^{4}$ & 1.82 \\
\hline 2.4 & 0.45 & $1.1 \cdot 10^{4}$ & 0.79 & 0.83 & $1.5 \cdot 10^{4}$ & 2.51 \\
\hline 2.8 & 0.52 & $1.3 \cdot 10^{4}$ & 1.03 & 0.97 & $1.8 \cdot 10^{4}$ & 3.29 \\
\hline 3.2 & 0.60 & $1.5 \cdot 10^{4}$ & 1.30 & 1.11 & $2.0 \cdot 10^{4}$ & 4.15 \\
\hline 3.6 & 0.67 & $1.7 \cdot 10^{4}$ & 1.60 & 1.24 & $2.3 \cdot 10^{4}$ & 5.10 \\
\hline
\end{tabular}


be damaged if the cell enters a high shear stress zone inside a certain part of the reactor (e.g., in the cavities of the circulation pump), where the shear stress level is beyond the threshold of the algae. Computational fluid dynamics (CFD) analyses on shear stress in centrifugal pumps show that the probability of cells entering regions inside the pump with shear stress levels that damage the cells depends on the residence time of the cells inside the pump, the rotational speed of the impeller, and the shape of the impeller (Song et al. 2003; Takiura et al. 1998; Zhou et al. 2003). The magnitude of the damage is therefore related to the proportion of the cells, $\varphi$, that pass this high shear stress zone per passage and the amount of passages $(n)$ over time:

$\frac{N_{\mathrm{r}}}{N_{0}}=(1-\varphi)^{\mathrm{n}}$

where $N_{\mathrm{r}}$ is the cell concentration of the sensitive algae remaining viable and $N_{0}$ is the cell concentration of sensitive algae before exposure. Figure 4 shows the percentage of intact cells remaining over time assuming that 1,5 , or $10 \%$ of the cells are being damaged per passage.

The number of passages through the pump depends on the length of the tubular PBR and the flow velocity. At a pumping speed of $2 \mathrm{~m}^{3} \mathrm{~h}^{-1}$, the culture is recirculated 50 times per hour in the PBR. This means that the number of passes per day is about 1200 . Even when only $1 \%$ of the cells pass a high shear zone, it is clear that all sensitive cells would be inactivated within 1 day. However, not all cells might be shear stress sensitive. Most likely, the cells which are in the dividing stage are especially vulnerable to shear stress. Assuming that at a given time about $30 \%$ of the microalgal cells are in the dividing stage (Coats and Heinbokel 1982) and that the generation time is about 1 day, the time that a cell is vulnerable to shear stress is about $7.2 \mathrm{~h}$ per day. In those $7.2 \mathrm{~h}$, the number of passages is 360 , which leads to an inactivation of $97 \%$ of the sensitive cells. Only $3 \%$ will remain for further growth, which

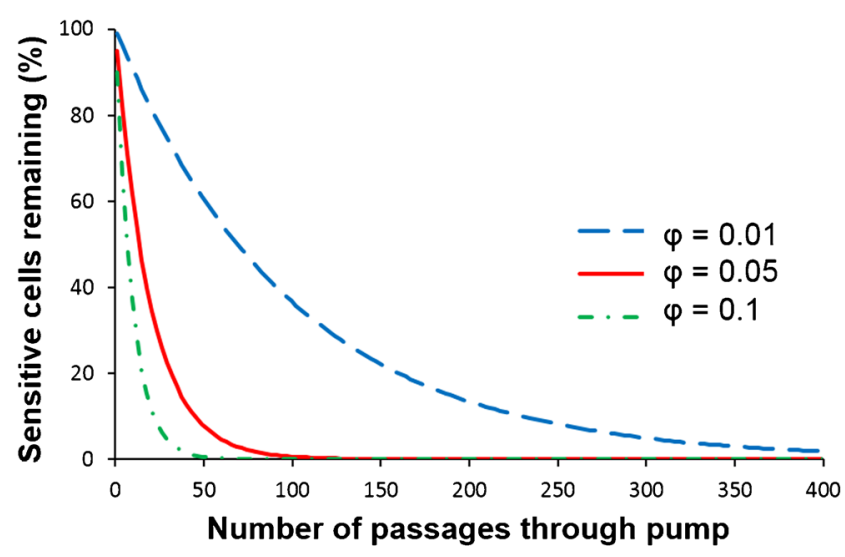

Fig 4 Percentage of remaining cells as an effect of passages through a pump and proportion of cells being damaged per passage is clearly too low to maintain or even increase the number of microalgae cells. This means that in the tubular PBR, almost all cells are expected to be inactivated within one or a few days, which is in line with the experimental observations.

Design of closed photobioreactor systems for shear sensitive microalgae

Theoretically, two possible routes are possible to avoid cell damage due to shear stress. The first one is reducing or avoiding high shear stress zones in the reactor. This option, however, might be quite difficult to achieve. Lowering the flow rate too much will lead to other problems, because high turbulence is needed for keeping the microalgae suspended and the use of light and nutrients is enhanced by turbulent mixing (Richmond 2013). Another option is to reduce the number of passages. Many commercial tubular PBRs consist of longer tubes with a length of $100 \mathrm{~m}$ (Pulz et al. 2013) and with flow velocities applied in PBRs between 0.3 and $0.5 \mathrm{~m} \mathrm{~s}^{-1}$ (Norsker et al. 2011). This reduces the number of passages of the shear stress sensitive cells, which are in the dividing stage, to about 90 per day. In the case of $1 \%$ of the cells being affected per pump passage in a commercial PBR, $60 \%$ of the sensitive cells would still be damaged. It is obvious that more cells will be damaged, if a higher percentage of the cells is affected per passage through the pump (Fig. 4). Considering that the time needed for cell proliferation is about 1 day, the time is too short to overcome the damage done by high shear stress, even if the high shear stress region is small.

The tolerance to shear stress of various strains seems to be selective to the choice of recirculation pumps. Microalgae with rigid cell walls are shear stress tolerant, while species lacking a cell wall, coccolithophores with calcium carbonate containing coccospheres and diatoms with fragile siliceous frustules are sensitive to shear stress (Leupold et al. 2013; Moheimani et al. 2011; Vandanjon et al. 1999). Phaeodactylum tricornutum is an exception among the diatoms. Its cell wall structure does not contain siliceous valves but rather the cells hace a more rigid polysaccharide cell wall (Borowitzka and Volcani 1978; Tesson et al. 2009). It therefore can be successfully cultivated in tubular PBRs with centrifugal pumps, although some reduction of productivity has been reported at higher flow rates causing high shear zones in the reactor (Alías et al. 2004; Silva Benavides et al. 2013).

The fact that I. galbana, S. costatum, and a species of the genus Chaetoceros were reported to be successfully cultivated in tubular PBRs recirculated with airlift pumps (Molina Grima et al. 1994; Krichnavaruk et al. 2005; Loubière et al. 2009; Monkonsit et al. 2011; Van Bergeijk et al. 2010) suggests that hydrodynamic forces exerted in the tubes of PBRs were probably not high enough to negatively affect the growth. Airlift pumps, which are causing lower shear stress than centrifugal pumps (Carvalho et al. 2006), seem to be the best option for 
the recirculation of shear stress sensitive microalgae. Peristaltic pumps, eccentric rotor pumps, and diaphragm pumps may be interesting alternatives as well. These pumps have been shown to be more gentle than centrifugal or positive displacement rotary vane pumps (Jaouen et al. 1999). However, further research on the actual shear stress levels occurring in these pumps is recommended in order to find whether shear stress levels are sufficiently low to allow successful algae cultivation in PBRs.

\section{Conclusion}

Four different microalgae species used as feed for shellfish in hatcheries were tested for their shear stress sensitivity. T. suecica was found to be the only shear stress tolerant species tested, which viability was not negatively affected by a maximum applied shear stress level of $88 \mathrm{~Pa}$. T. suecica was also successfully grown in a tubular PBR driven by a centrifugal pump. I. galbana, S. costatum, and C. muelleri were not able to grow in the tubular PBR recirculated by a centrifugal pump at its lowest speed. Shear stress levels between 1.2 and 5.4 Pa caused a reduction in viability of the shear stress sensitive species I. galbana, S. costatum, and C. muelleri. In order to increase the feasibility of the production of microalgae for aquaculture in fully-automated PBRs, high shear stress zones in the reactor (including the pump) should be avoided when designing a culture system for shear stress sensitive microalgal species.

Acknowledgments This study is supported by the Zeeuwse Tong project (Zeeland Sole project), co-funded by the European Fisheries Fund. The authors would like to thank Julius Frölich, Solveig Höfer, Zanina Ilieva, Scott Quainoo, Anna Jeworrek, Lennet Leuchter, Jolien Scholten and Jens Schouwenaars for their assistance working with the photobioreactor.

Open Access This article is distributed under the terms of the Creative Commons Attribution License which permits any use, distribution, and reproduction in any medium, provided the original author(s) and the source are credited.

\section{References}

Acién FG, Fernández JM, Magán JJ, Molina E (2012) Production cost of a real microalgae production plant and strategies to reduce it. Biotechnol Adv 30:1344-1353

Acién Fernández FG, Sánchez Pérez JA, Fernández Sevilla JM, García Camacho F, Molina Grima E (2000) Modeling of eicosapentaenoic acid (EPA) production from Phaeodactylum tricornutum cultures in tubular photobioreactors. Effects of dilution rate, tube diameter, and solar irradiance. Biotechnol Bioeng 68:173-183

Alías CB, García-Malea López MC, Acién Fernández FG, Fernández Sevilla JM, García Sánchez JL, Molina Grima E (2004) Influence of power supply in the feasibility of Phaeodactylum tricornutum cultures. Biotechnol Bioeng 87:723-733
Altman SA, Renders L, Rao G (1993) Comparison of trypan blue dye exclusion and fluorometric assays for mammalian cell viability determinations. Biotechnol Prog 9:671-674

Bondioli P, Della Bella L, Rivolta G, Chini Zittelli G, Bassi N, Rodolfi L, Casini D, Prussi M, Chiaramonti D, Tredici MR (2012) Oil production by the marine microalgae Nannochloropsis sp. F\&M-M24 and Tetraselmis suecica F\&M-M33. Bioresour Technol 114:567-572

Borowitzka MA (1999) Commercial production of microalgae: ponds, tanks, tubes and fermenters. J Biotechnol 70:313-321

Borowitzka MA, Volcani BE (1978) The polymorphic diatom Phaeodactylum tricornutum: Ultrastructure of its morphotypes. J Phycol 14:10-21

Camus T, Zeng C (2012) Reproductive performance, survival and development of nauplii and copepodites, sex ratio and adult life expectancy of the harpacticoid copepod, Euterpina acutifrons, fed different microalgal diets. Aquac Res 43:1159-1169

Carvalho AP, Meireles LA, Malcata FX (2006) Microalgal reactors: a review of enclosed system designs and performances. Biotechnol Prog 22:1490-1506

Chini Zittelli G, Rodolfi L, Biondi N, Tredici MR (2006) Productivity and photosynthetic efficiency of outdoor cultures of Tetraselmis suecica in annular columns. Aquaculture 261:932-943

Chisti Y (2010) Shear sensitivity. In: Flickinger MC (ed) Encyclopedia of industrial biotechnology, bioprocess, bioseparation and cell technology, vol 7. Wiley, New York, pp 4360-4398

Coats DW, Heinbokel J (1982) A study of reproduction and other life cycle phenomena in planktonic protists using an acridine orange fluorescence technique. Mar Biol 67:71-79

Contreras A, García F, Molina E, Merchuk J (1998) Interaction between $\mathrm{CO}_{2}$-mass transfer, light availability, and hydrodynamic stress in the growth of Phaeodactylum tricornutum in a concentric tube airlift photobioreactor. Biotechnol Bioeng 60:317-325

Draganovic V, Jørgensen SE, Boom R, Jonkers J, Riesen G, Van Der Goot AJ (2013) Sustainability assessment of salmonid feed using energy, classical exergy and eco-exergy analysis. Ecol Indic 34:277289

Dunstan GA, Volkman JK, Barrett SM, Garland CD (1993) Changes in the lipid composition and maximisation of the polyunsaturated fatty acid content of three microalgae grown in mass culture. J Appl Phycol 5:71-83

Durst F, Kikura H, Lekakis I, Jovanović J, Ye Q (1996) Wall shear stress determination from near-wall mean velocity data in turbulent pipe and channel flows. Exp Fluids 20:417-428

Fadavi A, Chisti Y (2005) Gas-liquid mass transfer in a novel forced circulation loop reactor. Chem Eng J 112:73-80

García Camacho F, Gallardo Rodríguez JJ, Sánchez Mirón A, Cerón García MC, Belarbi EH, Molina Grima E (2007) Determination of shear stress thresholds in toxic dinoflagellates cultured in shaken flasks. Implications in bioprocess engineering. Process Biochem 42:1506-1515

Geel C, Versluis W, Snel JFH (1997) Estimation of oxygen evolution by marine phytoplankton from measurement of the efficiency of Photosystem II electron flow. Photosynth Res 51:61-70

Gladue RM, Maxey JE (1994) Microalgal feeds for aquaculture. J Appl Phycol 6:131-141

Graham LE, Wilcox LW, Graham J (2009a) Green algae I - Introduction and prasinophyceans. In: Algae, 2nd edn. Pearson, San Francisco pp 353-372

Graham LE, Wilcox LW, Graham J (2009b) Haptophytes. In: Algae, 2nd edn. Pearson, San Francisco pp 170-185

Hussenot J, Lefebvre S, Brossard N (1998) Open-air treatment of wastewater from land-based marine fish farms in extensive and intensive systems: current technology and future perspectives. Aquat Living Resour 11:297-304 
Jaouen P, Vandanjon L, Quéméneur F (1999) Stress of microalgal cell suspensions (Tetraselmis suecica) in tangential flow filtration systems: the role of pumps. Bioresour Technol 68:149-154

Kaspar HF, Keys EF, King N, Smith KF, Kesarcodi-Watson A, Miller MR (2014) Continuous production of Chaetoceros calcitrans in a system suitable for commercial hatcheries. Aquaculture 420-421:1-9

Krichnavaruk S, Loataweesup W, Powtongsook S, Pavasant P (2005) Optimal growth conditions and the cultivation of Chaetoceros calcitrans in airlift photobioreactor. Chem Eng J 105:91-98

Laing I (1991) Cultivation of marine unicellular algae. MAFF Lab Leafl Num 67:31

Lee SJ, Go S, Jeong GT, Kim SK (2011) Oil production from five marine microalgae for the production of biodiesel. Biotechnol Bioprocess Eng 16:561-566

Leupold M, Hindersin S, Gust G, Kerner M, Hanelt D (2013) Influence of mixing and shear stress on Chlorella vulgaris, Scenedesmus obliquus, and Chlamydomonas reinhardtii. J Appl Phycol 25:485495

Loubière K, Olivo E, Bougaran G, Pruvost J, Robert R, Legrand J (2009) A new photobioreactor for continuous microalgal production in hatcheries based on external-loop airlift and swirling flow. Biotechnol Bioeng 102:132-147

Michels MHA, Slegers PM, Vermuë MH, Wijffels RH (2014) Effect of biomass concentration on the productivity of Tetraselmis suecica in a pilot-scale tubular photobioreactor using natural sunlight. Algal Res 4:12-18

Michels MHA, Van Der Goot AJ, Norsker NH, Wijffels RH (2010) Effects of shear stress on the microalgae Chaetoceros muelleri. Bioprocess Biosyst Eng 33:921-927

Moheimani NR (2013) Long-term outdoor growth and lipid productivity of Tetraselmis suecica, Dunaliella tertiolecta and Chlorella $\mathrm{sp}$ (Chlorophyta) in bag photobioreactors. J Appl Phycol 25:167-176

Moheimani NR, Isdepsky A, Lisec J, Raes E, Borowitzka MA (2011) Coccolithophorid algae culture in closed photobioreactors. Biotechnol Bioeng 108:2078-2087

Molina E, Fernández J, Acién FG, Chisti Y (2001) Tubular photobioreactor design for algal cultures. J Biotechnol 92:113-131

Molina Grima E, Sánchez Pérez JA, García Camacho F, García Sánchez JL, Acién Fernández FG, Lopéz Alonso D (1994) Outdoor culture of Isochrysis galbana ALII-4 in a closed tubular photobioreactor. J Biotechnol 37:159-166

Monkonsit S, Powtongsook S, Pavasant P (2011) Comparison between airlift photobioreactor and bubble column for Skeletonema costatum cultivation. Eng J 15:53-64

Muller-Feuga A (2013) Microalgae for aquaculture: the current global situation and future trends. In: Richmond A, Hu Q (eds) Handbook of microalgal culture. Wiley, Chichester, pp 613-627

Norsker NH, Barbosa MJ, Vermuë MH, Wijffels RH (2011) Microalgal production - a close look at the economics. Biotechnol Adv 29:24 27

Pronker AE, Peene F, Donner S, Wijnhoven S, Geijsen P, Bossier P, Nevejan NM (2015) Hatchery cultivation of the common cockle (Cerastoderma edule L.): From conditioning to grow-out. Aquacult Res 46:302-312

Pulz O (2001) Photobioreactors: production systems for phototrophic microorganisms. Appl Microbiol Biotechnol 57:287-293

Pulz O, Broneske J, Waldeck P (2013) IGV GmbH experience report, industrial production of microalgae under controlled conditions: innovative prospects. In: Richmond A, Hu Q (eds) Handbook of microalgal culture. Wiley, Chichester, pp 445-460
Ramírez-Duque JL, Ramos-Lucumi MA (2011) Hydrodynamic computational evaluation in solar tubular photobioreactors bends with different cross sections. Ciencia. Tecnologia y Futuro 4:59-72

Richmond A (2013) Biological principles of mass cultivation of photoautotrophic microalgae. In: Richmond A, Hu Q (eds) Handbook of microalgal culture. Wiley, Chichester, pp 169-204

Rotman B, Papermaster BW (1966) Membrane properties of living mammalian cells as studied by enzymatic hydrolysis of fluorogenic esters. Proc Natl Acad Sci USA 55:134-141

Sauriau PG, Baud JP (1994) Artificial filament breakage of the diatom Skeletonema costatum intended for mollusc aquaculture. Aquaculture 123:69-81

Silva Benavides AM, Torzillo G, Kopecký J, Masojídek J (2013) Productivity and biochemical composition of Phaeodactylum tricornutum (Bacillariophyceae) cultures grown outdoors in tubular photobioreactors and open ponds. Biomass Bioenerg 54:115-122

Song X, Throckmorton AL, Wood HG, Antaki JF, Olsen DB (2003) Computational fluid dynamics prediction of blood damage in a centrifugal pump. Artif Organs 27:938-941

Stoecker DK, Long A, Suttles SE, Sanford LP (2006) Effect of smallscale shear on grazing and growth of the dinoflagellate Pfiesteria piscicida. Harmful Algae 5:407-418

Takache H, Christophe G, Cornet JF, Pruvost J (2010) Experimental and theoretical assessment of maximum productivities for the microalgae Chlamydomonas reinhardtii in two different geometries of photobioreactors. Biotechnol Prog 26:431-440

Takiura K, Masuzawa T, Endo S, Wakisaka Y, Tatsumi E, Taenaka Y, Takano H, Yamane T, Nishida M, Asztalos B (1998) Development of design methods of a centrifugal blood pump with in vitro tests, flow visualization, and computational fluid dynamics: Results in hemolysis tests. Artif Organs 22:393-398

Tesson B, Genet MJ, Fernandez V, Degand S, Rouxhet PG, MartinJézéquel V (2009) Surface chemical composition of diatoms. ChemBioChem 10:2011-2024

Tredici MR (2010) Photobiology of microalgae mass cultures: Understanding the tools for the next green revolution. Biofuels 1: 143-162

Van Bergeijk SA, Salas-Leiton E, Cañavate JP (2010) Low and variable productivity and low efficiency of mass cultures of the haptophyte Isochrysis aff. galbana (T-iso) in outdoor tubular photobioreactors. Aquac Eng 43:14-23

Van Riemsdijk LE, Snoeren JPM, Van Der Goot AJ, Boom RM, Hamer RJ (2010) Particle size effects in colloidal gelatin particle suspensions. J Food Eng 101:394-401

Vandanjon L, Rossignol N, Jaouen P, Robert JM, Quéméneur F (1999) Effects of shear on two microalgae species. Contribution of pumps and valves in tangential flow filtration systems. Biotechnol Bioeng 63:1-9

Vejrazka C, Janssen M, Streefland M, Wijffels RH (2012) Photosynthetic efficiency of Chlamydomonas reinhardtii in attenuated, flashing light. Biotechnol Bioeng 109:2567-2574

Wichterle K, Sobolík V, Lutz M, Denk V (1996) Shear rate on centrifugal pump impeller. Chem Eng Sci 51:5227-5228

Zhou W, Zhao Z, Lee T, Winoto S (2003) Investigation of flow through centrifugal pump impellers using computational fluid dynamics. Int J Rotating Mach 9:49-61

Zhu CJ, Lee YK (1997) Determination of biomass dry weight of marine microalgae. J Appl Phycol 9:189-194

Zmora O, Grosse DJ, Zou N, Samocha TM (2013) Microalgae for aquaculture: practical implications. In: Richmond $\mathrm{A}, \mathrm{Hu} \mathrm{Q}$ (eds) Handbook of microalgal culture. Wiley, Chichester, pp 628-652 